\title{
TWO MECHANISMS OF DIAMOND PHASE FORMATION DURING MAGNETRON SPUTTER DEPOSITION OF AMORPHOUS CARBON FILMS
}

\author{
A. Galdikas ${ }^{a, b}$ and A. Ibenskas ${ }^{a}$ \\ ${ }^{a}$ Physics Department, Kaunas University of Technology, Studentu 50, LT-51368 Kaunas, Lithuania \\ ${ }^{\mathrm{b}}$ Department of Physics, Mathematics and Biophysics, Kaunas University of Medicine, Eiveniu 4, \\ LT-3007 Kaunas, Lithuania
}

Received 26 May 2004

Dedicated to the 100th anniversary of Professor K. Baršauskas

\begin{abstract}
The diamond phase formation mechanisms are analysed by a new phenomenological model of deposition of diamond-like carbon (DLC) films on $\mathrm{Si}(001)$ substrate. Experimental observations that make base for this model are reviewed briefly. Only the main processes, such as adsorption of carbon atoms on the surface, formation of SiC, diamond, and graphite sites, are assumed to take place. Compressive stress, induced by ion subplantation, is regarded as a main factor causing the transformation of graphite to diamond. Relationship between stress and ion energy is given by Davis' formula. According to this model, dependences of film deposition rate versus time and dependences of film composition versus film thickness are calculated that are in agreement with experimental ones. Also, the ratio of $s p^{3} / s p^{2}$ volume fractions as a function of substrate bias voltage was calculated. Modelling of experimental curves show that under conditions of sputter deposition of DLC films there are at least two diamond phase formation mechanisms: (i) on the surface during carbon adsorption, and (ii) in the bulk of film by subplantation induced graphite transition to lonsdaleite (hexagonal diamond).
\end{abstract}

Keywords: thin films, diamond deposition, carbon, magnetron sputtering, kinetic modelling

PACS: 07.05.Tp, 81.05.Uw, 81.15.Aa

\section{Introduction}

Ion beam deposition (IBD) is widely used technique to grow hydrogen free carbon films having diamond-like properties. Ion bombardment is the main cause of stress $[1,2]$ so it is absolutely necessary to achieve the nucleation and growth of tetrahedral amorphous carbon (ta-C) films. High compressive stresses induced by ion bombardment and high temperature in thermal spikes represent conditions for the formation of $s p^{3} \mathrm{C}-\mathrm{C}$ bonds [3-5]. The thermal spike is a highly disrupted, very hot and small region of nanometre dimensions or a line (ion trajectory inside the target), which evolves during the slowing down process of the incident ion, when the excess energy of the ion is converted to thermal energy of target atoms. The density, $s p^{3}$ fraction, compressive stress, and electrical resistivity were found to depend strongly on the ion energy and pass through a maximum at bombarding ion energies ranging from 50 to $240 \mathrm{eV}[1,6]$. Within this energy window, the roughness of DLC surfaces is decreased significantly, compared to surfaces produced below critical impingement energy of approximately $50 \mathrm{eV}$ when the growth of graphitic clusters is promoted on the surface [7]. On the contrary, the use of high-energy $(10-15 \mathrm{keV})$ ions affects drastically the film structure and causes film growth enhanced as mixture of graphitic structure.

Lifshitz [8,9], Robertson [10], and Davis [11] proposed models of ta-C film growth based on subplantation mechanism. In Davis' model, the compressive stress is estimated assuming stress production due to subplantation of atoms with incident ion flux $j$ and stress release due to thermally activated relaxation processes during the thermal spike

$$
\sigma \propto \frac{Y}{1-\nu} \cdot \frac{E_{\mathrm{i}}^{1 / 2}}{R / j+\rho\left(E_{\mathrm{i}} / E_{\mathrm{R}}\right)^{5 / 3}} .
$$

The compressive film stress in Davis' formula (1) is given where $E_{\mathrm{i}}$ is incident ion energy, $E_{\mathrm{R}}$ is the en- 
ergy of rearrangements in thermal spike, $Y$ is Young's modulus, $\nu$ is the Poisson ratio, $R$ is the growth rate, $j$ is a relative flux of bombarding ions, and $\rho$ is a constant.

The model predicts maximum stress at bombarding ion energies $E=20 \mathrm{eV}$ if $R / j=1, E_{\mathrm{R}}=3 \mathrm{eV}$, and $\rho=0.016$. At higher energies $(E>200 \mathrm{eV})$ the model predicts strong stress reduction.

These models give a good agreement with experimental points considering ta-C film characteristic parameters on bombarding ion energies. However, kinetic modelling of time dependences of surface and bulk composition provides more detailed information about diamond phase formation mechanisms because reaction rate constants are obtained.

In our previous work [3] the growth kinetics of ta-C films on Si by magnetron sputtering was considered experimentally and theoretically. The experimental kinetics of deposition rates for different bias voltages is plotted in Fig. 1. The curves have characteristic minimum and maximum at initial stages of deposition and remain almost constant at later stages. The integrated deposition rate on bias voltage is shown in Fig. 2. The curve is not monotonous with respect to the bias. The $s p^{3} / s p^{2} \mathrm{C}-\mathrm{C}$ bonds ratio dependence on bias presented in Fig. 3 is like a mirror reflection of the Fig. 2 curve. In order to analyse experimental data, a kinetic model was proposed, which agreed qualitatively and quantitatively with experimental points of film growth kinetics. Nevertheless, this model involved a significant number of unknown phenomenological coefficients. In this work, after revising the previous model, we proposed a new model with significantly reduced number of coefficients. The model takes into account only the main processes: formation of the diamond phase on the surface by adsorption and in the bulk - by a compressive stress.

\section{Model}

In accordance with the conclusions of the previous model [3] the main processes taking place during growth of the ta-C film by magnetron sputter deposition are the following:

(1) adsorption of carbon atoms;

(2) formation of $\mathrm{SiC}$ and $s p^{2}, s p^{3}$ bonded carbon sites on the surface;

(3) formation of $s p^{3}$ bonded carbon sites in the bulk of the film.

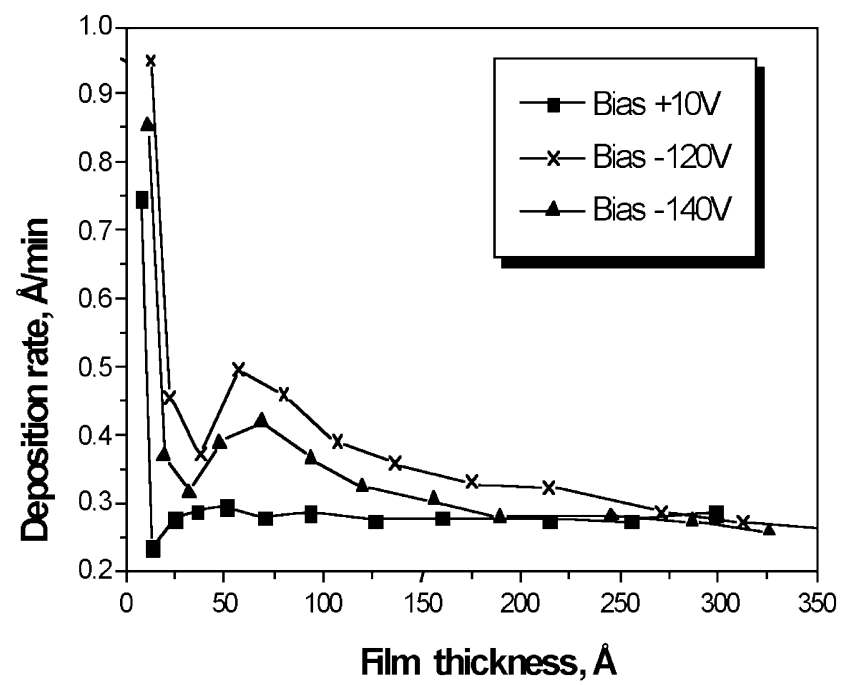

Fig. 1. The experimental kinetics of deposition rates for different bias voltages [4].

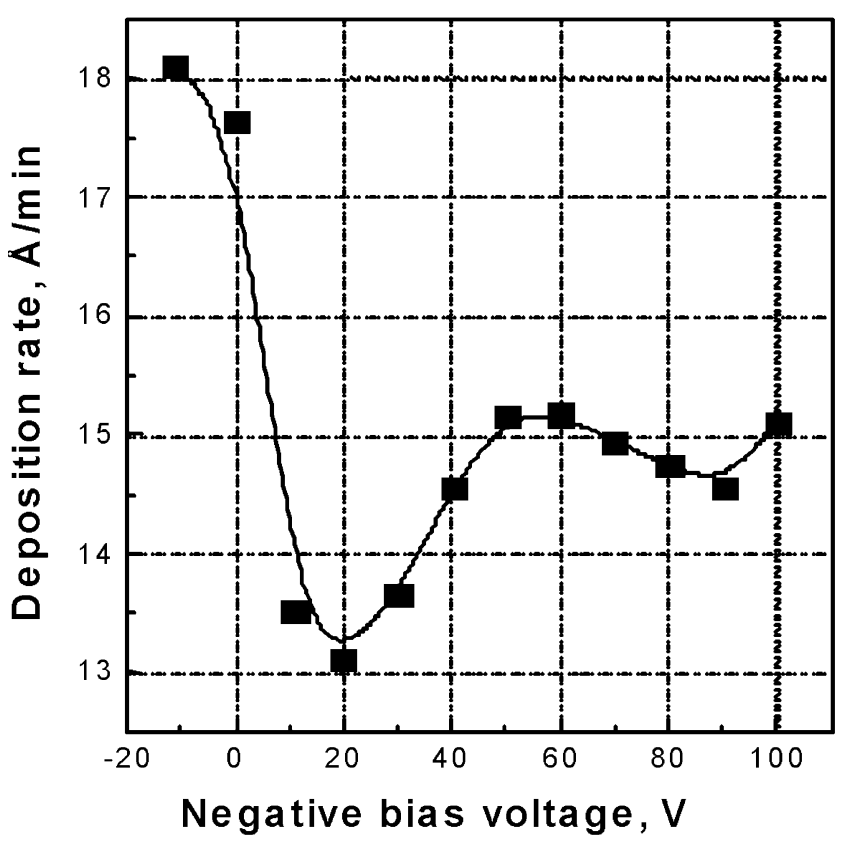

Fig. 2. The dependence of the film deposition rate on the bias voltage [4].

According to these considerations, there are only four types of different particles taking part in growing film: $\mathrm{Si}, \mathrm{SiC}, s p^{2}$ and $s p^{3}$ bonded $\mathrm{C}$ atoms. Their relative concentrations in $K$ th monolayer are $c_{1}^{(K)}, c_{2}^{(K)}$, $c_{3}^{(K)}$, and $c_{4}^{(K)}$, respectively.

Single $\mathrm{C}$ atoms arriving on the surface also contribute to film growth but they are incorporated into $\mathrm{SiC}, s p^{2}$ or $s p^{3}$ sites after adsorption.

The formation of chemical compounds is described by rate equations. We assume that, according to re- 


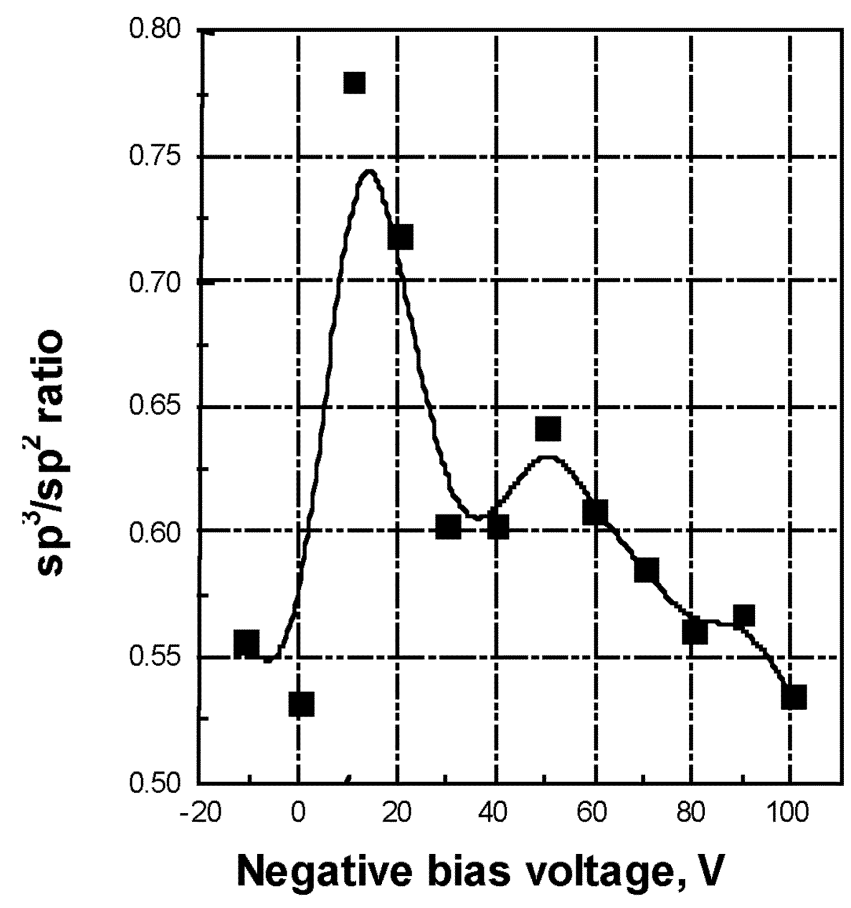

Fig. 3. The dependence of the ratio of $s p^{3}$ and $s p^{2}$ bonded carbon volume fractions on the substrate bias voltage [4].

action $\mathrm{Si}+\mathrm{C} \rightarrow \mathrm{SiC}, \mathrm{Si}$ atoms can form $\mathrm{SiC}$ links, but only on the surface. The time variation of concentration of atoms bonded in $\mathrm{SiC}$ sites on the surface $(K=1)$ is expressed as

$$
\left(\frac{\mathrm{d} c_{2}^{(1)}}{\mathrm{d} t}\right)_{\mathrm{SiC}}=R_{1}^{(1)} c_{1}^{(1)} i_{\mathrm{C}}
$$

where $R_{1}^{(1)}$ is the reaction rate constant, and $i_{\mathrm{C}}$ is a relative flux of carbon atoms arriving to the surface.

Rupture of SiC links is a negligible process not included in the model.

The $s p^{3}$ bonded carbon sites can be formed on the surface $(K=1)$ as well as in the bulk of the film $(K>1)$, but in different ways and with different rate constants. In deeper layers high local stresses arise and temperature increases in spikes due to ion bombardment, resulting in graphite transformation to diamond (lonsdaleite) [12]. This process is described by the rate equation

$$
\left(\frac{\mathrm{d} c_{4}^{(K)}}{\mathrm{d} t}\right)_{s p^{3}}=z^{(K)} c_{3}^{(K)} i_{0},
$$

where $z^{(K)}$ is the reaction rate constant. It has Gaussian dependence on depth and involves Davis' formula (see Eq. (1); Davis' formula estimates the compres- sive stress in a film induced by ion beam bombardment),

$$
\begin{aligned}
z^{(K)} & =z_{0} \exp \left[-\frac{1}{2}\left(\frac{d \cdot K-R_{\mathrm{p}}}{\Delta R_{\mathrm{p}}}\right)^{2}\right], \\
z_{0} & =B \frac{\left(E / E_{\text {crit }}\right)^{1 / 2}}{\left(i_{\mathrm{C}} / i_{0}\right)+0.016 \rho\left(E / E_{0}\right)^{5 / 3}},
\end{aligned}
$$

where $i_{0}$ is a relative flux of arriving to the surface bombarding ions, $d$ is a mean monolayer thickness, $K$ is the number of the monolayer, $R_{\mathrm{p}}$ is the ion $\left(\mathrm{Ar}^{+}\right)$penetration depth, $\Delta R_{\mathrm{p}}$ is a width of the ion damaged region around $R_{\mathrm{p}}, E$ is a bombarding ion energy, $E_{\text {crit }}$ is a threshold energy for ion implantation, $E_{0}$ is a displacement energy, $\rho$ is a materialdependent parameter, and $B$ is a coefficient of proportionality.

The quantity $i_{\mathrm{C}} / i_{0}$ refers to the ratio of depositing flux to bombarding ion flux. According to Davis' model, deposition rate $V_{\mathrm{A}}$ should be used instead of $i_{\mathrm{C}}$.

As mentioned above, the formation of $s p^{3}$ bonded carbon sites also takes place on the surface. This means that $\mathrm{SiC}$ sites are covered with diamond. This process is defined in the following way:

$$
\left(\frac{\mathrm{d} c_{4}^{(1)}}{\mathrm{d} t}\right)_{s p^{3}}=r_{2} c_{2}^{(1)} i_{\mathrm{C}}^{4}
$$

where $r_{2}$ is the reaction rate constant, and $i_{\mathrm{C}}$ is raised to the power of four with respect to the mass action law, since four $\mathrm{C}$ atoms are required for every $\mathrm{C}$ atom already located on the surface, to form all of the four possible $\sigma$ bonds.

The $s p^{2}$ bonded carbon is formed only on the surface covering $\mathrm{SiC}$ and $s p^{3}$ sites with graphite. It is specified by the rate equation

$$
\left(\frac{\mathrm{d} c_{3}^{(1)}}{\mathrm{d} t}\right)_{s p^{2}}=r_{3}^{(1)} c_{2}^{(1)} i_{\mathrm{C}}^{4}+r_{1}^{(1)} c_{4}^{(1)} i_{\mathrm{C}}^{4}
$$

where $r_{3}^{(1)}$ and $r_{1}^{(1)}$ are the reaction rate constants for the growth of graphitic phase on the $\mathrm{SiC}$ sites and on the diamond sites, respectively. The quantity $i_{\mathrm{C}}^{4}$ is used again because every $\mathrm{C}$ atom in the graphitic phase also makes four (three $\sigma$ and one $\pi$ ) bonds with four other $\mathrm{C}$ atoms.

The bombarding ion energies and temperatures considered here are not sufficient for graphitization of formed diamond in the bulk of film, so this process is not included. 
Table 1. Parameters used in calculations. The values of reaction rate constants are chosen taking into account the best fit of experimental points using the previous model [3].

\begin{tabular}{cccc}
\hline Parameter & Value & Parameter & Value \\
\hline$E_{\mathrm{p}}$ & 35 & $r_{10}^{(1)}$ & 0.4 \\
$E_{0}$ & 75 & $r_{20}$ & 0.9 \\
$E_{\text {crit }}$ & 18 & $r_{30}^{(1)}$ & 0.0001 \\
$\chi_{10}$ & 1 & $d$ & 3 \\
$\chi_{20}$ & 4 & $B$ & 0.6 \\
$R_{10}^{(1)}$ & 1 & $\rho$ & 400 \\
\hline
\end{tabular}

Taking all ta-C formation mechanisms and rate equations (2)-(7) into account, deposition rate is expressed as

$$
\begin{aligned}
V_{\mathrm{A}}= & R_{1}^{(1)} c_{1}^{(1)} i_{\mathrm{C}}+r_{1}^{(1)} c_{4}^{(1)} i_{\mathrm{C}}^{4}+r_{2} c_{2}^{(1)} i_{\mathrm{C}}^{4} \\
& +r_{3}^{(1)} c_{2}^{(1)} i_{\mathrm{C}}^{4}+\chi_{1} c_{3}^{(1)} i_{\mathrm{C}}^{4}+\chi_{2} c_{4}^{(1)} i_{\mathrm{C}}^{4},
\end{aligned}
$$

where $\chi_{1}$ and $\chi_{2}$ are the frequency probabilities $\chi_{i, j}=$ $\alpha_{i, j} i_{i}\left(\mathrm{~s}^{-1}\right)$ of adsorption of carbon atoms on $s p^{2}$ and $s p^{3}$ sites. Values of the other parameters are presented in Table 1.

The following set of rate equations is obtained for the surface $(K=1)$ :

$$
\left\{\begin{array}{l}
\frac{\mathrm{d} c_{1}^{(1)}}{\mathrm{d} t}=-R_{1}^{(1)} c_{1}^{(1)} i_{\mathrm{C}}, \\
\frac{\mathrm{d} c_{2}^{(1)}}{\mathrm{d} t}=R_{1}^{(1)} c_{1}^{(1)} i_{\mathrm{C}}-r_{2} c_{2}^{(1)} i_{\mathrm{C}}^{4}-r_{3}^{(1)} c_{2}^{(1)} i_{\mathrm{C}}^{4}, \\
\frac{\mathrm{d} c_{3}^{(1)}}{\mathrm{d} t}=r_{1}^{(1)} c_{4}^{(1)} i_{\mathrm{C}}^{4}+r_{3}^{(1)} c_{2}^{(1)} i_{\mathrm{C}}^{4}, \\
\frac{\mathrm{d} c_{4}^{(1)}}{\mathrm{d} t}=r_{2} c_{2}^{(1)} i_{\mathrm{C}}^{4}-r_{1}^{(1)} c_{4}^{(1)} i_{\mathrm{C}}^{4} .
\end{array}\right.
$$

Reaction rate equations for the deeper monolayers $(K>1)$ are

$$
\left\{\begin{array}{l}
\frac{\mathrm{d} c_{1}^{(k)}}{\mathrm{d} t}=V_{\mathrm{A}}\left(c_{1}^{(k-1)}-c_{1}^{(k)}\right), \\
\frac{\mathrm{d} c_{2}^{(k)}}{\mathrm{d} t}=V_{\mathrm{A}}\left(c_{2}^{(k-1)}-c_{2}^{(k)}\right), \\
\frac{\mathrm{d} c_{3}^{(k)}}{\mathrm{d} t}=V_{\mathrm{A}}\left(c_{3}^{(k-1)}-c_{3}^{(k)}\right)-z^{(K)} c_{3}^{(k)} i_{0}, \\
\frac{\mathrm{d} c_{4}^{(k)}}{\mathrm{d} t}=V_{\mathrm{A}}\left(c_{4}^{(k-1)}-c_{4}^{(k)}\right)+z^{(K)} c_{3}^{(k)} i_{0} .
\end{array}\right.
$$

Actually, reaction rate constants depend on bombarding ion energy. Mathematical expressions of these de- pendences are not unambiguously determined yet. We define them as $R=R_{0} \sqrt{E}$, where $R_{0}$ is a constant, and

$$
\begin{aligned}
\chi_{1} & =\chi_{10} \sqrt{E}, \\
\chi_{2} & =\chi_{20} \sqrt{E}, \\
r_{1}^{(1)} & =r_{10}^{(1)} \sqrt{E} \\
r_{2} & =r_{20} \sqrt{E} \\
r_{3}^{(1)} & =r_{30}^{(1)} \sqrt{E} \\
R_{1}^{(1)} & =R_{10}^{(1)}\left[1-\exp \left(-\frac{E}{E_{\text {crit }}}\right)\right] .
\end{aligned}
$$

\section{Results and discussion}

Calculations have been performed by numerical integration of Eqs. (9) and (10) with the following boundary condition: the maximum thickness of the film is assumed to be 300 monolayers. If the film deposited is not as thick as 300 monolayers then all of the rest monolayers are designated as a part of a silicon wafer. In the beginning of deposition process all monolayers consist of silicon atoms only.

The time dependences of the deposition rate $V_{\mathrm{A}}$ for different substrate bias are plotted in Fig. 4. We note here that time dependences of the deposition rate and surface composition were calculated for several different bias voltages. The bombarding ion energy is equal to $E_{\mathrm{p}}-e V_{\mathrm{b}}$, i.e. the sum of the average energy of the plasma discharge and the energy acquired due to substrate bias. Thus, varying $V_{\mathrm{b}}$ introduces changes to bombarding ion energy. Also, this is the way to affect $z^{(k)}$ and film composition since ion energy $E$ is included in the $z^{(k)}$ definition, see Eqs. (4) and (5). Finally, this means that the deposition rate also depends on the bias voltage, as it can be observed in Fig. 4.

It is obvious that the calculated time dependences of the deposition rate (Fig. 4) are qualitatively similar to the experimental one (Fig. 1). At the beginning of the process, the deposition rate is high, and it reaches the maximum value very soon. Then the deposition rate decreases rapidly until the minimum value is passed. The latter is followed by rise of the deposition rate again, and a second maximum value is observed. The initial stage of deposition ends when the deposition rate 


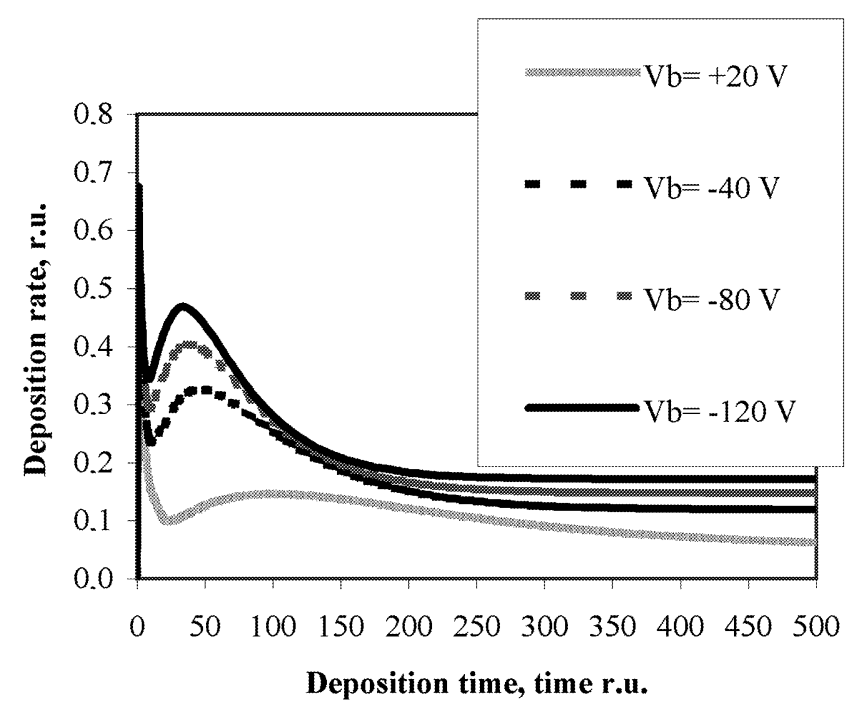

Fig. 4. The calculated time dependences of deposition rate $V_{\mathrm{A}}$ for a ta-C film deposited with different bias voltages $V_{\mathrm{b}}$ assuming that all reaction rate constants depend on bombarding ion energy (r.u., relative units).

becomes nearly constant. The higher the negative substrate bias voltage, the larger the maximum of the deposition rate.

The deposition rate and time are given in relative units because calculated dependences still need some adjustment in order to make the model appropriate to the real process of film deposition. This might be obtained by variation of reaction rate constants. The curve of the deposition rate is raised by increasing the coefficients $\chi_{20}$ and $r_{20}$ (the formation of diamond sites becomes faster) or reducing $R_{10}^{(1)}$ (the growth of $\mathrm{SiC}$ sites becomes slower). The increase of the coefficient $r_{20}$ forces the minimum of the deposition rate to rise and move left and the second maximum of the deposition rate also to move left. The rearrangement results in decrease of difference between the maximum and the minimum values of the deposition rate, and the curve becomes flatter. The second maximum could be obtained sharper by increasing the coefficient $r_{30}^{(1)}$, which means faster growth of the graphitic phase on $\mathrm{SiC}$ sites.

We also calculated time dependences of surface composition. Since they are quite similar for different bias voltages, only dependence for $V_{\mathrm{b}}=-80 \mathrm{~V}$ is plotted here in Fig. 5.

Apparently, the film grows rapidly until major part of the surface of a silicon wafer is covered with silicon carbide, as it is seen from Figs. 4 and 5(b). The minimum value of the deposition rate is observed at approximately the same moment as the maximum value

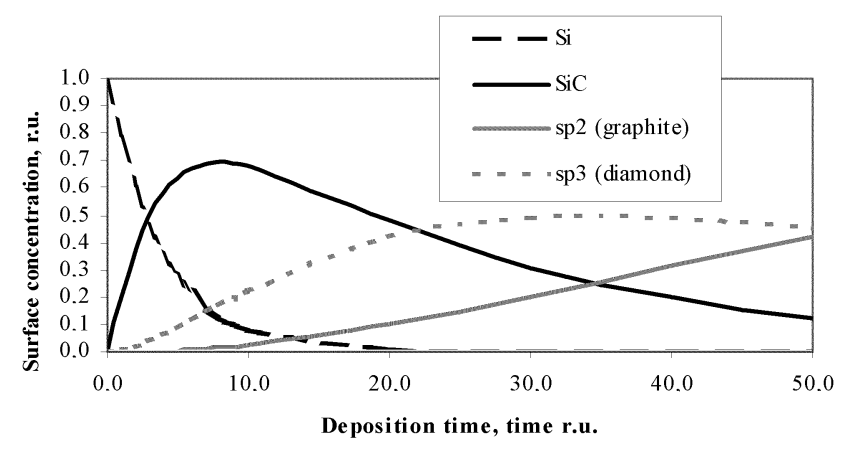

(a)

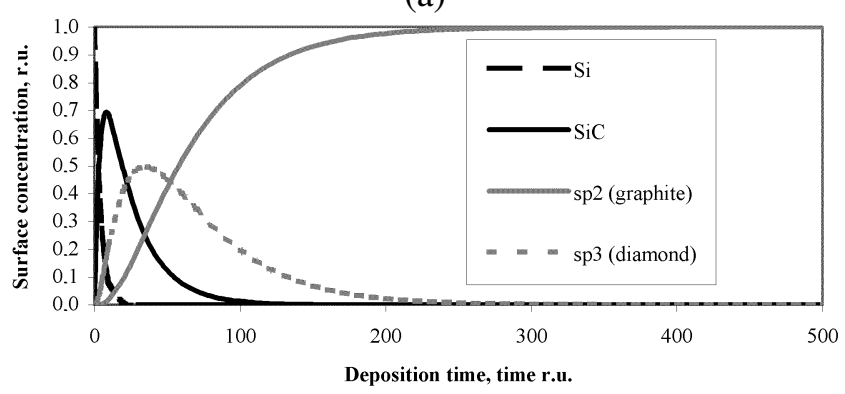

(b)

Fig. 5. The calculated time dependences of surface composition: (a) after initial stage of the growth; (b) after the whole process of deposition.

of $\mathrm{SiC}$ surface concentration due to low sticking of carbon atoms to $\mathrm{SiC}$, much lower than to $\mathrm{Si}$. Assuming that $\mathrm{SiC}$ improves the formation of $s p^{3}$ sites, it is natural to suppose that more carbon atoms on the surface are bonded in $s p^{3}$ sites than in $s p^{2}$ sites at the initial stage of deposition (Fig. 5(b)). Carbon atoms arriving on the surface are adsorbed well on $s p^{3}$ sites, therefore, maximum surface concentration of carbon atoms bonded in $s p^{3}$ sites corresponds to the maximum value of the deposition rate (Figs. 4 and 5(b)). Sticking of carbon atoms to diamond phase ( $s p^{3}$ sites) is explained by thermodynamic considerations. Diamond phase is unstable under usual conditions so it tends to a state of minimum free energy by adsorbing new carbon atoms. At later stages of the film growth, the whole surface is covered with graphite (Fig. 5(a)) because $s p^{2}$ sites are formed on $\mathrm{SiC}$ as well as on $s p^{3}$ sites. At this state the deposition rate is nearly constant because it depends only on the coefficient of sticking of $\mathrm{C}$ atoms to graphite that is constant.

The relation between the maximum of the deposition rate (Fig. 4) and surface concentration of carbon atoms bonded in $s p^{3}$ sites (Fig. 5(b)) allows one to confirm that increase of ion energy improves the formation of $s p^{3}$ sites on the surface. For positive bias voltage, the second maximum of the deposition 

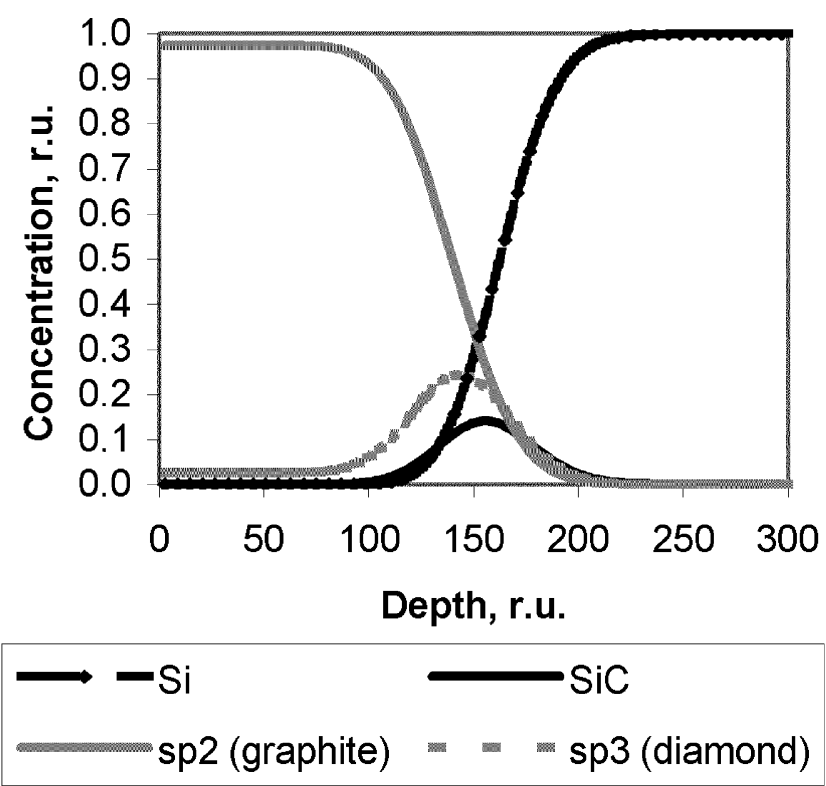

(a)

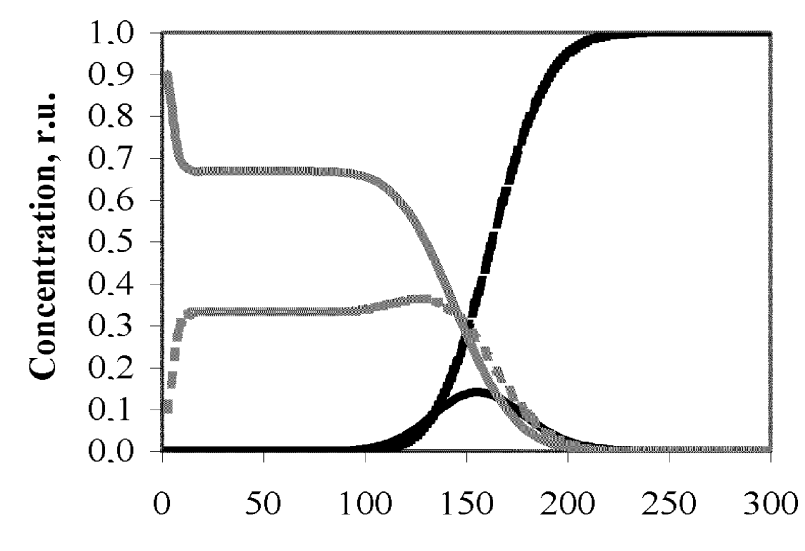

Depth, r.u.

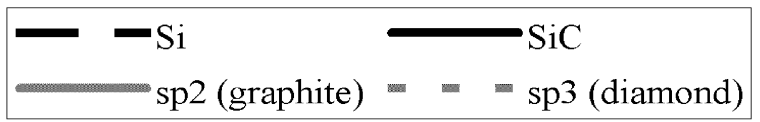

(b)

Fig. 6. The calculated dependences of film composition on depth after a deposition period of 1000 time r.u.: (a) with bias voltage $V_{\mathrm{b}}=+20 \mathrm{~V}$; (b) with bias voltage $V_{\mathrm{b}}=-80 \mathrm{~V}$.

rate is very flat and appears later than for negative bias voltage. This is in agreement with the experimental observations (see Fig. 1) that low bombarding ion energies (when $V_{\mathrm{b}}>0$ ) lead to the formation of smaller amounts of diamond and low deposition rate. The positive bias voltage also causes a longer initial stage until the deposition rate reaches a steady state.

The film composition after a deposition period of 1000 time r.u. (relative units) for different bias voltages is plotted in Fig. 6.

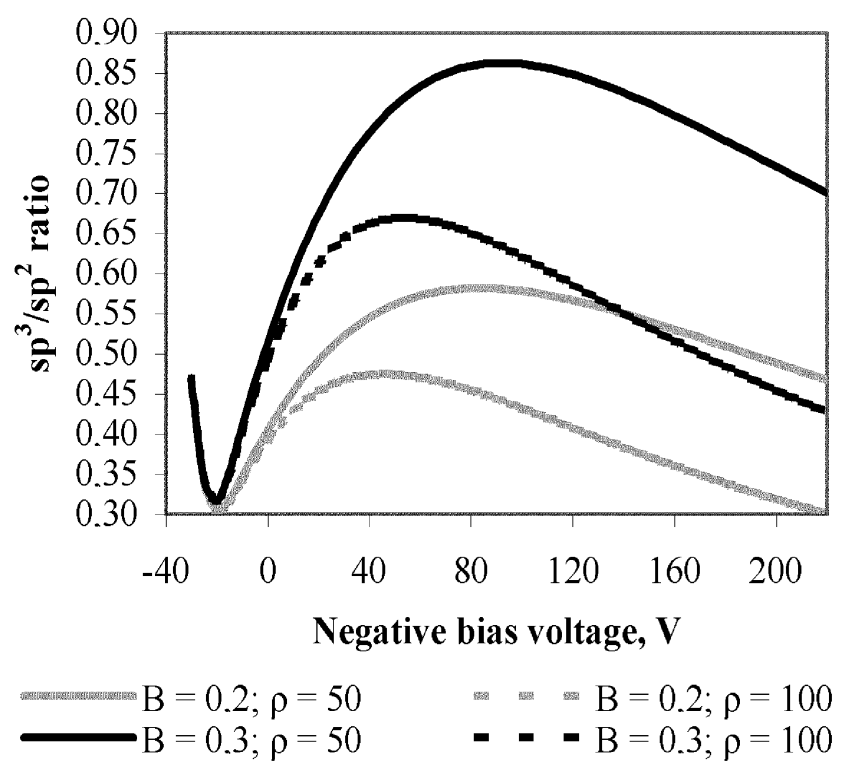

Fig. 7. The calculated dependence of the ratio $s p^{3} / s p^{2}$ of volume fractions in deposited film after a deposition period of 1000 time r.u. when the dependence of reaction rate constants on bombarding ion energy is taken into account.

In both cases (when deposited with $V_{\mathrm{b}}=+20 \mathrm{~V}$ and $V_{\mathrm{b}}=-80 \mathrm{~V}$ ), the film composition is dominated by silicon in the deepest monolayers that are close to the wafer. The traces of $\mathrm{SiC}$, diamond and graphitic phases are observed at a depth of about 200 r.u. With decreasing the depth, the quantities of $\mathrm{SiC}$, diamond and graphitic phases increase. The concentration of atoms bonded in $\mathrm{SiC}$ sites passes the maximum value at a depth of approximately $160 \mathrm{r}$.u. and then decreases rapidly enough. In addition, surface composition is dominated by the graphitic phase ( $s p^{2}$ sites), and the diamond phase ( $s p^{3}$ sites) is located mainly in the bulk of the film at a depth of 30-150 r.u. The reasons of such a distribution are discussed above. The higher negative bias voltage applied, the greater is the concentration of carbon atoms bonded in $s p^{3}$ sites, in agreement with previous considerations and experimental observations.

The experimental $s p^{3} / s p^{2}$ volume ratio curve has two maxima corresponding to $V_{\mathrm{b}}=-15 \mathrm{~V}$ and $-50 \mathrm{~V}$, see Fig. 3. The second maximum is treated here with greater attention, since the calculated dependence of the $s p^{3} / s p^{2}$ ratio presented in Fig. 7 has also the maximum corresponding to $V_{\mathrm{b}}=-50 \mathrm{~V}$. The maximum is quite planar and stretched to the region of higher bias voltages. This maximum arises because of ion bombardment induced compressive stresses in the growing film which makes preferential bonding of $s p^{3}$. 
The $s p^{3} / s p^{2}$ volume ratio is quite large at the beginning of the calculated curve in Fig. 7 and decreases with increasing $V_{\mathrm{b}}$. This increase in the $s p^{3} / s p^{2}$ ratio is because of nucleation of the diamond phase on the surface and corresponds with the first maximum that is observed in the experimental $s p^{3} / s p^{2}$ ratio curve at $-20 \mathrm{~V}$ (Fig. 3). Unfortunately, at present we are not able to obtain quantitative fit of the first maximum. Probably the dependences of reaction rates on the ion energy (Eq. (11)) are more complex.

The magnitude of the $s p^{3} / s p^{2}$ ratio is governed by the parameter $B$. With increasing $B$, the curve rises up and the maximum value moves slightly to the region of the higher bias voltages. Higher values of $\rho$ decrease the maximum value of the $s p^{3} / s p^{2}$ ratio and drag it to the region of lower bias voltages. Here $\rho$ is of the order of $10^{2}$ compared to 1 in Davis' model [11].

For positive bias voltage, all the calculated dependences of the $s p^{3} / s p^{2}$ ratio in Fig. 7 approach each other, and the ratio of $s p^{3} / s p^{2}$ volume fractions does not depend on parameters $B$ and $\rho$.

\section{Conclusions}

1. There are two main processes contributing to formation of the diamond phase in the film: (i) growth of $s p^{3}$ bonded carbon sites on the surface; (ii) transformation of $s p^{2}$ bonded carbon to $s p^{3}$ bonded carbon in the bulk of the film, i. e. transformation of the graphitic phase to the lonsdaleite phase.

2. The deposition rate rises with increasing bias voltage as a result of ion energy dependent reaction rate constants $\chi_{2}, r_{2}$, and $R_{1}^{(1)}$.

3. The minimum value of the film deposition rate is observed at approximately the same moment as maximum surface concentration of $\mathrm{SiC}$ links due to low coefficient of adsorption of carbon atoms on $\mathrm{SiC}$ phase. The maximum value of the deposition rate corresponds to the maximum surface concentration of $s p^{3}$ bonded carbon atoms because $s p^{3}$ bonded carbon highly adsorbs single carbon atoms in order to minimize the Gibbs free energy.

4. The calculated dependences of the ratio of $s p^{3} / s p^{2}$ volume fractions on bias voltage qualitatively fit the experimental dependence. The calculated curve rises up with the value of parameter $B$.
By increasing parameter $\rho$, the calculated curve is lowered, and the maximum value of the $s p^{3} / s p^{2}$ ratio is shifted to the region of lower bias voltages.

\section{References}

[1] D.R. McKenzie, Tetrahedral bonding in amorphous carbon, Rep. Prog. Phys. 59, 1611-1664 (1996).

[2] A.C. Ferrari, S.E. Rodil, J. Robertson, and W.I. Milne, Is stress necessary to stabilise $s p^{3}$ bonding in diamondlike carbon?, Diamond Relat. Mater. 11, 994-999 (2002).

[3] S. Logothetidis, P. Patsalas, M. Gioti, A. Galdikas, and L. Pranevicius, Growth kinetics of sputtered amorphous carbon thin films: Composition studies and phenomenological model, Thin Solid Films 376, 56-66 (2000).

[4] A. Galdikas, S. Logothetidis, M. Gioti, P. Patsalas, and L. Pranevicius, The kinetics of sputtered deposited carbon on silicon: A phenomenological model, Diamond Relat. Mater. 8, 490-494 (1999).

[5] M. Liao, F. Qin, J. Zhang, Z. Liu, S. Yang, and Z. Wang, Ion bombardment as the initial stage of diamond film growth, J. Appl. Phys. 89(3), 1983-1985 (2001).

[6] S. Zhang, H.T. Johnson, G.J. Wagner, W.K. Liu, and K.J. Hsia, Stress generation mechanisms in carbon thin films grown by ion-beam deposition, Acta Materialia 51, 5211-5222 (2003).

[7] X.L. Peng, Z.H. Barber, and T.W. Clyne, Surface roughness of diamond-like carbon films prepared using various techniques, Surf. Coatings Technol. 138, 23-32 (2001).

[8] Y. Lifshitz, S.R. Kasi, and J.W. Rabalais, Subplantation model for film growth from hyperthermal species: Application to diamond, Phys. Rev. Lett. 62(11), 1290-1293 (1989).

[9] Y. Lifshitz, S.R. Kasi, J.W. Rabalais, and W. Eckstein, Subplantation model for film growth from hyperthermal species, Phys. Rev. B 41(15), 10468-10480 (1990).

[10] J. Robertson, The deposition mechanism of diamondlike a-C and a-C:H, Diamond Relat. Mater. 3, 361-368 (1994).

[11] C.A. Davis, A simple model for the formation of compressive stress in thin films by ion bombardment, Thin Solid Films 226, 30-34 (1993).

[12] P.J. Fallon, V.S. Veerasamy, C.A. Davis, J. Robertson, G.A.J. Amaratunga, W.J. Milne, and J. Koskinen, Properties of filtered-ion-beam-deposited diamondlike carbon as a function of ion energy, Phys. Rev. B 48(7), 4777-4782 (1993). 


\title{
DU DEIMANTO FAZĖS SUSIDARYMO MECHANIZMAI AMORFINĖS ANGLIES DANGŲ MAGNETRONINĖS SINTEZĖS METU
}

\author{
A. Galdikas ${ }^{a, b}$, A. Ibenskas ${ }^{\text {a }}$ \\ ${ }^{\text {a }}$ Kauno technologijos universitetas, Kaunas, Lietuva \\ ${ }^{\mathrm{b}}$ Kauno medicinos universitetas, Kaunas, Lietuva
}

\section{Santrauka}

Nagrinèti deimanto fazès susidarymo būdai bei pateiktas deimanto tipo anglies dangu nusodinimo ant kristalinio silicio padèklo fenomenologinis modelis. Trumpai apžvelgti eksperimentiniai tyrimai, kuriais pagrịstas šis modelis. Ivertinti svarbiausi dangos nusodinimo vyksmai: anglies atomu igertis, SiC kristalitu bei $s p^{2}$ ir $s p^{3}$ hibridizacijos anglies kristalitu susidarymas. Pagrindiniu veiksniu, lemiančiu grafito virtimą deimantu dangos tūryje, laikomi gniuždantys itempiai, kuriuos sukelia joninis apšaudymas. Itempius su jonų energija sieja Davis'o formulè. Remiantis tokiu modeliu, apskaičiuotos dangos storèjimo spartos priklausomybès nuo laiko, kurios kokybiškai gerai sutampa su analogiškomis eksperimentinemis kreivemis. Taip pat rastos dangos sudèties (paviršiuje) priklausomybès nuo laiko, dan- gos sudèties (tūryje) priklausomybès nuo gylio ir $s p^{3} / s p^{2}$ santykio priklausomybès nuo padèklo priešitampio. Tų kreiviu palyginimas su storèjimo spartos kreive bei su eksperimentu rezultatais leidžia daryti išvadą, kad deimanto fazè dangoje susidaro dviem būdais: 1) vykstant anglies atomu igerčiai paviršiuje, 2) grafitui virstant deimantu dangos tūryje. Pastebèta, kad danga storeja lecčiausiai, kai $\mathrm{SiC}$ kiekis paviršiuje yra didžiausias, kadangi $\mathrm{C}$ atomai blogai igeriami ant $\mathrm{SiC}$. Deimanto fazé gerai igeria $\mathrm{C}$ atomus, todel dangos storejjimo spartos ir $s p^{3}$ ryšių koncentracijos maksimumai stebimi maždaug tuo pačiu metu. Apskaičiuota $s p^{3} / s p^{2}$ santykio priklausomybè nuo padèklo priešitampio turi maksimumą ties -(50-60) V, kaip ir eksperimentinè kreivè. 